\begin{tabular}{l|c|c}
\hline ISSN: 0001-5113 & ACTA ADRIAT., & ORIGINAL SCIENTIFIC PAPER \\
AADRAY & $58(2): 245-260,2017$ & \\
\hline \hline
\end{tabular}

\title{
Zooplankton of a stressed area in the Damietta coast of the Mediterranean Sea
}

\author{
Wael S. ELTOHAMY ${ }^{*}$, Ahmad ALZENY² and Yasmine A. M. AZAB ${ }^{1}$ \\ ${ }^{1 * Z o o l o g y}$ Department, Faculty of Science, Damietta University, Egypt \\ ${ }^{2}$ National institute of Oceanography and Fisheries, Balteem, Egypt \\ *Corresponding author, e-mail: waelsalah@du.edu.eg
}

\begin{abstract}
The spatial pattern of zooplankton communities at Damietta coast, southeastern Mediterranean was studied to assess the impact of human activities on the abundance and community structure. Twenty-five stations from five different stressed sites were sampled in June-July 2014. Thirty-four zooplankton taxa were recorded, in addition to the larvae of copepods and meroplankton. Copepoda was the most abundant group among which, Oithona nana, Euterpina acutifrons, and Parvocalanus cirrostratus were the most frequent. The calanoid copepod Pseudodiaptomus trihamatus is a new record for the Mediterranean Sea that may have been introduced via ballast water. Multivariatel Univariate analyses demonstrated that 1) the environmental variables and zooplankton communities represented significant differences among five sites; 2) the spatial variations of community structure were undoubtedly due to land-based effluents; and 3) among all environmental variables, salinity and phytoplankton biomass had the major determining effects on the spatial patterns of zooplankton categories. The results indicates that not only the discharged water makes the Damietta coast at risk, but also the ballast water is not less dangerous. Hence, we emphasize the need for activation of the ballast water management to reduce the risk of future species invasions.
\end{abstract}

Key words: zooplankton, Land base effluents, Damietta coast, Copepods, Pseudodiaptomus trihamatus

\section{INTRODUCTION}

The Egyptian Mediterranean coastline is of great economic and environmental significance as it combines localities of intensive socio-economic activities and urbanized areas. This study area is a part of the Nile delta that is located in the southeastern corner of the Mediterranean Sea, the Damietta coast $\left(31^{\circ} 20^{\prime}\right.$ and $\left.31^{\circ} 34^{\prime}\right)$. The study area covers most of the Egyptian prolific fish larvae-producing region (EL-GHOBASHY, 2009; ELTOHAMY, 2012) as well as being a famous habitat for several marine birds (IBRAHIM, 2011). During the last two decades, this area has been exposed to multiple changes mainly due to local on-going human activities. These activities include unsustainable practices such as building processes (or such as constructions), agricultural activities, tourism and growth of industrial areas. Effluent discharges are, however, probably the most significant issue since sewage drainage systems eventually discharge directly into the Damietta coast through several channels (HAMZA, 2006). Now, this is a global 
issue for coasts where the land-based effluents often triggers eutrophic conditions as well as alteration of water quality (LEVINTON, 2001). The response of certain groups of organisms to changes in water quality is important for monitoring the environmental stress. Examples of the most frequently used groups of organisms (biotic water quality indicators) include benthos, phytoplankton, and macrophytes (AZRINA et al., 2006; OMAR, 2010). Several studies have been carried out on the importance of zooplankton communities as indicators of changes in marine systems (BONNET \& FRID, 2004; MOLINERO et al., 2005; FALCÃO et al., 2012) and many studies have focused on the influence of human activities on zooplankton communities (VARELA et al., 2006; LEONARDO et al., 2009; VADADI-FÜLÖP et al., 2009). The link between land-based effluents and changes in water quality parameters may suggest a direct or indirect link between land-based effluents and zooplankton community structure. Although most of the sampling stations during the present study may be subjected to different kinds of land-based effluents, Damietta harbor, which is used for commercial shipping, lies under addition stress of maritime activities and the untreated ballast water from foreign countries. Once the ballast water is discharged, and the non-indigenous species are released, they can become established in the recipient ecosystem and start to spread (KOLAR \& LODGE, 2001). These invasive species can pose a risk to biodiversity (MCGEOCH et al., 2010).

The current study employed considerably large number of stations in four different sites impacted by different human activities during summer to assess the response of zooplankton species to human disturbances, especially to land-based effluents which increase considerably during this season with the increasing of agricultural activities and greatly affected the zooplankton species in terms of abundance and community structure. The variations in species composition often provide important signals to changes in the water quality and also explore the relative importance of some environmental variables which control the community structure (FLEEGER et al., 2003; DODSON et al., 2005).

\section{MATERIAL AND METHODS}

\section{The study area}

The present study was carried out at four sites at the Damietta coat: in the Damietta harbor, Damietta Nile estuary, Barge Canal, and the Damietta coastal region (Fig. 1). The harbor is semi-closed basin with an area of $3.1 \mathrm{~km}^{2}$ and depth range of $5-15 \mathrm{~m}$, connected to the sea through the navigational canal and to the Nile estuary by the Barge Canal which is $4.5 \mathrm{~km}$ long and $5-7 \mathrm{~m}$ depth. Inside the harbor, there are several small basins delivered for different maritime activities. The Barge Canal receives directly freshwater from the Nile River, sewage and agricultural wastes From Sananya and Ras El Bar (cities at Damietta governorate). The Damietta Nile estuary extends for $13 \mathrm{~km}$ from Farskour dam (south to Damietta city) to open
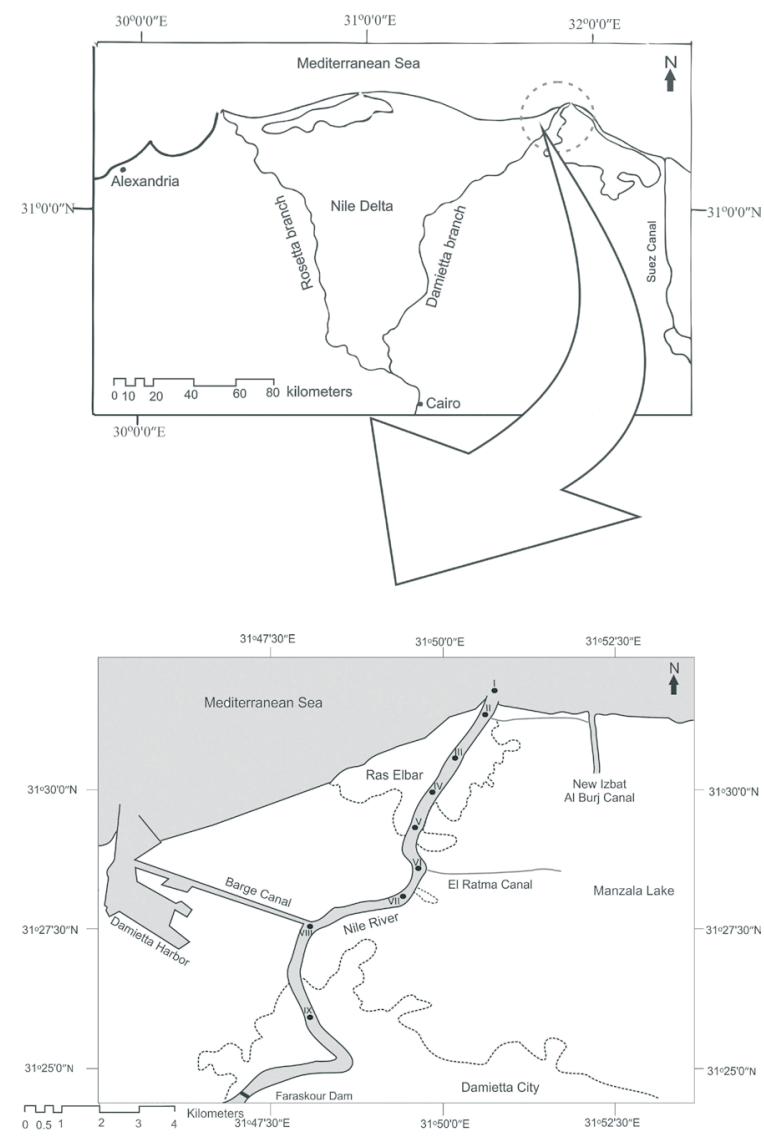

Fig. 1. Map of the study area showing the positions of the sampling stations 
at the Mediterranean Sea (Fig. 1). Farskour dam completely isolated the estuary from the Nile river and thus the water properties in the estuary are mainly controlled by the land runoff (Manzalla lake effluents, sewage, agricultural and industrial inputs), and the tidal regime. The last sampling site is the coastal region which extends for $15 \mathrm{~km}$. At this site the sampling was carried out in the shallow water; the maximum average depth is $15 \mathrm{~m}$, and so we think that the water quality in this area is affected reasonably by the untreated terrestrial effluents which flow from many spots along the coast.

Twenty five stations were chosen for this study in the four sites; 6 at the coastal region, 5 at the Damietta harbor, 4 at the Barge canal, and 10 at the Damietta Nile estuary (5 at the estuary downstream \& 5 at the estuary upstream).

\section{Sampling methods and laboratory techniques}

Zooplankton samples were collected twice in June and July 2014, with surface water samples collected concurrently for the measurement of environmental parameters. Zooplankton collections were taken using a $54-\mu \mathrm{m}$ mesh plankton ring-net of $45 \mathrm{~cm}$ mouth diameter hauled vertically slowly from the bottom to the surface at each station. Given the short distances sampled, volume filtered was calculated at the product of mouth area and distance hauled to the surface, assuming $100 \%$ filtration efficiency. Samples were killed immediately in 5\% buffered formalin and later preserved in 10\% formalin. In the laboratory, zooplankton species were identified and taxon abundance (per cubic meter) was estimated from $5 \mathrm{ml}$ subsample, taken after thorough mixing of the entire sample $(100 \mathrm{ml})$. Many publications and taxonomic references were used for identification, such as TREGOUBOFF \& ROSE (1957); EDMONDSON, (1959); GONZALEZ \& BOWMAN (1965); NISHIDA (1985) and BOLTOVSKOY (1999).

Chlorophyll $a$, hydrographic parameters (temperature, salinity, transparency, dissolved oxygen, $\mathrm{pH})$ and nutrients $\left(\mathrm{PO}_{4}, \mathrm{NO}_{3}, \mathrm{NO}_{2}\right.$, $\mathrm{NH}_{4}$, and $\mathrm{SiO}_{3}$ ) were measured. The surface water temperature was measured to the nearest $0.5^{\circ} \mathrm{C}$ with a mercury thermometer and salinity to the nearest part per thousand with a refractometer. Water transparency was estimated by a standard Secchi disc (25 cm in diameter) and $\mathrm{pH}$ with a digital $\mathrm{pH}$ meter. Dissolved oxygen, nutrients, and phytoplankton biomass (chlorophyll $a$ ) were determined according to the methods described by STRICKLAND \& PARSONS (1972).

\section{Statistical analysis}

One way ANOVA analysis with Tukey's-b procedure was applied to test the spatial differences between the environmental variables. This univariate analysis was carried out using the statistical program SPSS v18.0. Data were log-transformed before analysis.

Canonical ordination was performed to assess the association of zooplankton species with environmental factors using the CANOCO 4.5 package. The spatial patterns of either zooplankton communities or environmental variables were analyzed by the routine cluster analysis which was performed by using PAST program (HAMMER et al., 2001), based on either Bray-Curtis similarity index (BRAY \& CURTIS, 1957) or Euclidean distance from log-transformed physical- chemical data.

\section{RESULTS}

\section{Water Quality}

The reasonable match of the results of Tukey's-b test between the sampling sites for both salinity and Secchi disc transparency (Table 1) indicates the significant influence of land use on the water quality parameters. Damietta harbor and coastal region characterized by considerably higher values of these variables comparing to the other regions with a noticeable decreasing in the estuary upstream indicate the large influence of freshwater discharge in this region. Dissolved oxygen and $\mathrm{pH}$ values for stations in the coastal region were significantly lower than those of the other stations, and for the nutrients, only phosphate concentration was considerably higher 
(Table 1). The concentrations of silicate were significantly higher in Damietta harbor than the other sites which showed negligible differences in silicate concentrations. Other nutrients $\left(\mathrm{NO}_{3}\right.$, $\mathrm{NO}_{2}$, and $\mathrm{NH}_{4}$ ) concentrations were generally high in the waters of the study area, especially in the Nile estuary upstream. Nerveless, the regions contained very different concentrations of chlorophyll $a$, clearly indicating that there is a high variability in the response of planktonic algae when faced with different concentrations of nutrients. Nile estuary and Barge canal contained a high phytoplankton biomass, while the remaining two sites (coastal region\& Damietta harbor) contained lower concentrations of chlorophyll $a$, despite their high concentrations of phosphate \& silicate respectively (Table 1).
Therefore, Nile estuary and Barge canal can be safely classified as eutrophic, as in addition to their high concentrations of N-nutrients, they have high concentrations of chlorophyll $a$.

\section{Species distribution and variations in species number and abundance}

A list of zooplankton species observed during the survey and their average abundance and frequency of occurrence at each site were given in Table 2. A total of 34 zooplankton species were identified, in addition to the larval stages of different groups. Most of them were Copepoda (16 species). Rotifera formed 6 species, Cladocera 4 species, and Larvacea 3 species, while Ostracoda, Mysidacea, Nematoda, Mollusca and

Table 1. The mean values and standard variations of different physico-chemical parameters and chlorophyll a at the sampled sites. Note the significant differences between the sampling sites based on One Way ANOVA with Tuckey's-b test. SDT = Sechi Disk Transparency, Chl a = chlorophyll a

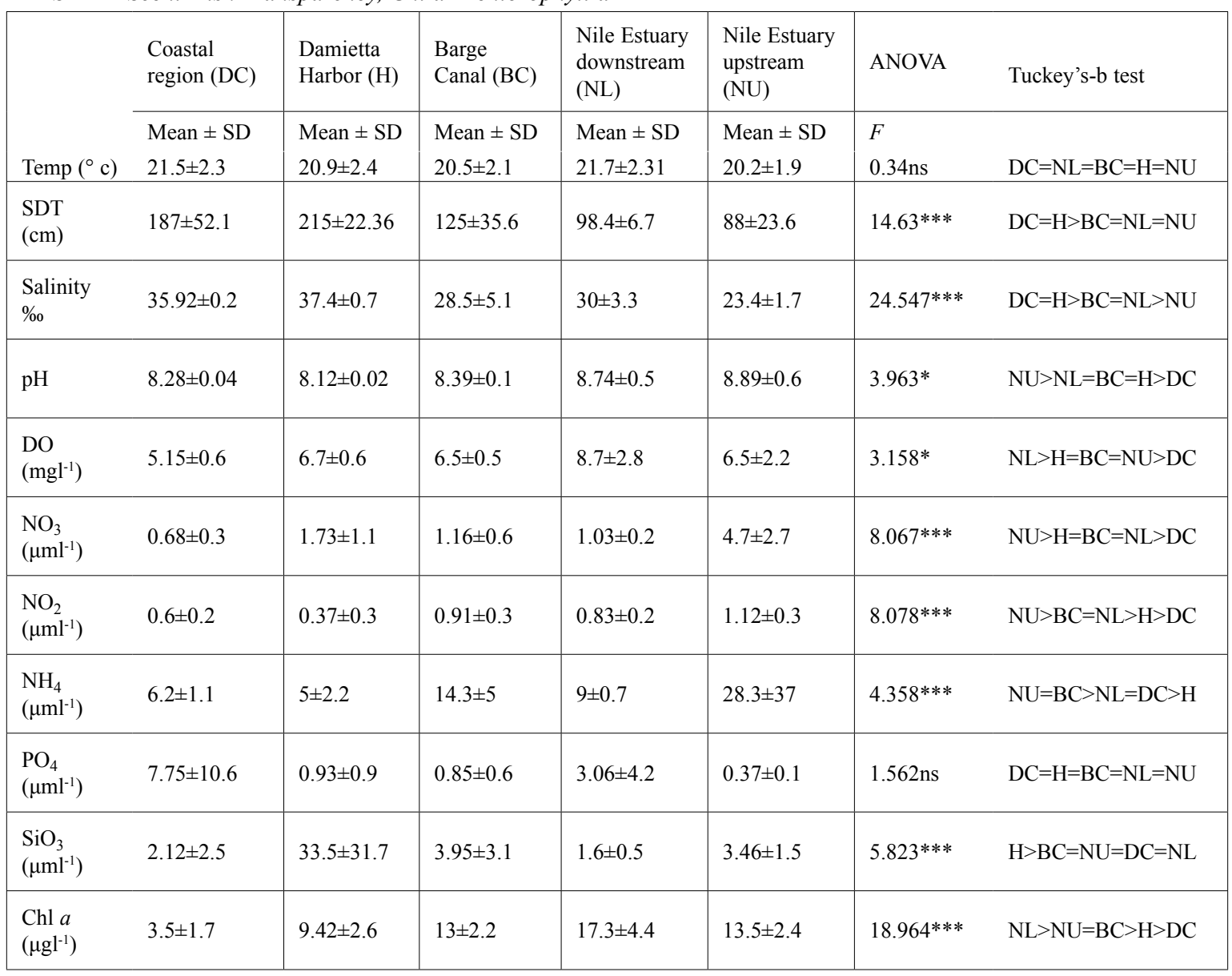

The values followed $*$ and $* * *$ are significant at $\mathrm{P}<0.05$ and 0.001 respectively, ns $=$ not significant 
Chaetognatha were represented by only one species each.

A dendrogram of the species distribution using groups average clustering on Bray-Curtis similarities based on species abundance from the five sampling sites is shown in Figure 2. The cluster analysis resulted in the 34 species in addition to the larvae of copepods and meroplankton falling into 6 groups (I-VI) at $45 \%$ similarity level. Group I was composed of 18 of the highest frequent and abundant items, and thus representing the primary contributors to the succession of the zooplankton community. The other five groups (II-VI) represented mostly by the rare assemblages with low abundance and/ or occurrence (Fig. 2, Table 2). The analysis of similarities demonstrated significant differences among the groups $(r=0.895)$.

The average values of species number and

Table 2. Mean abundance (individuals m-3) and Frequency of occurrence (\%), of zooplankton species at the sampled sites

\begin{tabular}{|c|c|c|c|c|c|c|}
\hline & Abbreviations & $\begin{array}{l}\text { Coastal } \\
\text { region }\end{array}$ & $\begin{array}{l}\text { Damietta } \\
\text { harbor }\end{array}$ & Barge canal & $\begin{array}{l}\text { Estuary } \\
\text { downstream }\end{array}$ & $\begin{array}{l}\text { Estuary } \\
\text { upstream }\end{array}$ \\
\hline \multicolumn{7}{|l|}{ Monogononta } \\
\hline Brachionus calyciflorus (Pallas,1766) & Bcal & & & & & $1.8(40)$ \\
\hline B. plicatilis (Müller,1786) & Bpli & $1.9(33.3)$ & & $314.6(50)$ & $86(100)$ & $139.7(100)$ \\
\hline Keratella quadrata (Müller,1786) & Kqua & & & $3.6(50)$ & & $9.4(80)$ \\
\hline S. okai (Sudzuki,1964) & Soka & $2.1(16.7)$ & $7.1(80)$ & $442.2(100)$ & $227.7(100)$ & $75.7(80)$ \\
\hline S. pectinata (Ehrenberg,1832) & Spec & $0.33(16.7)$ & $0.7(20)$ & $19.1(75)$ & $4.9(60)$ & $1.7(60)$ \\
\hline Free living nematodes & Flnem & & $0.73(20)$ & $0.61(25)$ & $2.8(60)$ & $0.4(20)$ \\
\hline Copepoda & & & & & & \\
\hline Calanoida & & & & & & \\
\hline Parvocalanus crassirostris (Dahl F., 1894) & Pcra & $45.8(83.3)$ & $239.5(100)$ & $117.3(100)$ & $26.5(100)$ & $5.9(60)$ \\
\hline Paracalanus parvus (Claus, 1863) & Ppar & $7.3(50)$ & $13.9(100)$ & $19.6(75)$ & $7.6(80)$ & \\
\hline Paracalanus sp. & Pasp & & $37.2(100)$ & $8.6(25)$ & & \\
\hline Pseudodiaptmus trihamatus (Wright, 1937) & Psed & & & $0.6(25)$ & $6.5(80)$ & $1.3(40)$ \\
\hline \multicolumn{7}{|l|}{ Cyclopoida } \\
\hline Acanthocyclops americanus (Marsh, 1893) & Aame & & & $0.6(25)$ & & $2.5(60)$ \\
\hline Oithona simplex (Farran, 1913) & Osim & $52.2(100)$ & $116.8(100)$ & $181.6(100)$ & $35.5(100)$ & $35.2(60)$ \\
\hline Paracyclops sp. & Prcsp & & & $3.7(25)$ & $9.9(100)$ & $3.8(60)$ \\
\hline Harpacticoida & & & & & & \\
\hline Clytemnestra scutellata (Dana, 1849) & Cscu & $5.8(100)$ & $15.8(80)$ & $10.7(50)$ & $0.8(20)$ & \\
\hline Euterpina acutifrons (Dana,1874) & Eacu & $78.6(100)$ & $359(100)$ & $223.6(100)$ & $61.5(100)$ & $18.8(100)$ \\
\hline Microsetella norvegica (Boeck,1865) & Mnor & & & & & $0.4(20)$ \\
\hline Poecilostomatoida & & & & & & \\
\hline Oncaea spp. & Onsp & $2.1(33.3)$ & $31.6(100)$ & $12.2(50)$ & & \\
\hline Cyclopoida Nauplii & Cynap & $404.3(100)$ & $301.7(100)$ & $390.7(100)$ & $127.8(100)$ & $41.3(100)$ \\
\hline Harpacticoida Nauplii & Hanap & $455.8(100)$ & $668(100)$ & $409.4(100)$ & $76.6(100)$ & $32.7(100)$ \\
\hline Calanoida Nauplii & Canap & $45.4(100)$ & $270.4(100)$ & $223.6(100)$ & $765.4(100)$ & $11.9(100)$ \\
\hline
\end{tabular}




\begin{tabular}{|c|c|c|c|c|c|c|}
\hline Cyclopoida Copepodite & Сусор & $604.8(100)$ & $1324.7(100)$ & $795.7(100)$ & $567.6(100)$ & $235.7(100)$ \\
\hline Harpacticoida Copepodite & Hacop & $211.5(100)$ & $578.3(100)$ & $458.4(100)$ & $31.5(100)$ & $25.1(80)$ \\
\hline Calanoida Copepodite & Cacop & $80.6(100)$ & $704.1(100)$ & $562.9(100)$ & $26.6(100)$ & $22.14(80)$ \\
\hline Cladocera & & & & & & \\
\hline Penilia avirostris (Dana, 1849) & Pavi & & $1(20)$ & & & \\
\hline Podon intermedius (Lilljeborg, 1853) & Pint & $1.9(16.7)$ & $20.9(80)$ & $14.7(50)$ & & \\
\hline Podon leuckartii (G.O. Sars, 1862) & Pleu & & $16.8(80)$ & $10.1(50)$ & & \\
\hline $\begin{array}{l}\text { Evadne tergestina (Claus, 1877) } \\
\text { Ostracoda }\end{array}$ & Eter & $2.2(66.7)$ & $84.8(100)$ & $10.7(25)$ & & \\
\hline $\begin{array}{l}\text { Cypridina mediterrianea (Claus) } \\
\text { Mysidacea }\end{array}$ & Cyme & $0.33(16.7)$ & & $0.7(25)$ & $1.85(60)$ & \\
\hline Leptomysis mediterranea (G.O.Sars, 1877) & Lmed & & & & $0.8(20)$ & \\
\hline Mollusca & & & & & & \\
\hline Pteropoda & & & & & & \\
\hline $\begin{array}{l}\text { Limacina inflata (d'Orbigny, 1863) } \\
\text { Chaetognatha }\end{array}$ & Linf & $19.7(100)$ & $4(100)$ & $9.4(100)$ & $0.8(20)$ & $3.8(100)$ \\
\hline Sagitta friderici (Ritter.Zàhony,1911) & Sfri & $5.7(83.3)$ & $36(100)$ & $40(75)$ & $2.62(60)$ & $0.74(20)$ \\
\hline Larvacea & & & & & & \\
\hline Appendicularia sicula $($ Fol,1874) & Asic & $11.4(83.3)$ & $50.1(100)$ & $16.6(50)$ & & \\
\hline $\begin{array}{l}\text { Oikopleura dioica }(\text { Fol, 1872) } \\
\text { Meroplanktonic larvae }\end{array}$ & Odio & $81.9(100)$ & $294.4(100)$ & $124.3(75)$ & $0.8(20)$ & $0.74(20)$ \\
\hline Ectopleura dumortierii (Van Ben. 1844) & Edum & & $0.54(20)$ & $1.7(50)$ & & \\
\hline Medusa of Obelia spp. & Mobe & $0.33(16.7)$ & $1.1(20)$ & $2.9(25)$ & $6.9(40)$ & $0.4(20)$ \\
\hline Polychaetes Spionidae & Pspin & $921.9(100)$ & $90(100)$ & $409.8(100)$ & $150.4(100)$ & $411.9(100)$ \\
\hline Polychaetes nereidae & Pner & $11.7(100)$ & $4.8(40)$ & $204.3(75)$ & $42.9(100)$ & $358.3(60)$ \\
\hline Polychaetes serpulidae & Pser & $85.96(100)$ & $5.3(40)$ & $100.2(100)$ & $36.2(100)$ & $362.2(60)$ \\
\hline Cirripedes larvae & Clar & $103.7(100)$ & $44.5(100)$ & $101.7(100)$ & $190.2(100)$ & $28.5(100)$ \\
\hline Decapods larvae & Dlar & $0.35(16.7)$ & $1.1(40)$ & & $0.8(20)$ & \\
\hline Crustacean eggs & Cegg & $4.9(50)$ & $90.6(100)$ & $18.8(75)$ & $0.51(20)$ & \\
\hline Molluscs Lamellibranch veligers & Lbve & $396.4(100)$ & $282.2(100)$ & $440.2(100)$ & $149.6(100)$ & $1917.5(100)$ \\
\hline Starfish Bipinnaria Larvae & Bilar & $0.4(16.7)$ & $6.9(40)$ & $1.1(25)$ & & \\
\hline Ascidiaceans larvae & Aslar & & $2.1(40)$ & $1.5(25)$ & & \\
\hline Fish eggs & Fegg & $0.33(16.7)$ & & $0.6(25)$ & & \\
\hline Fish larvae & Flar & $0.4(16.7)$ & & & & \\
\hline
\end{tabular}

abundance of zooplankton communities at each of the five sampling sites were shown in Figure 3 (the larvae of copepods and Meroplankton are not included in this figure). The species count showed a maximum mean value at both Nile estuary downstream and Damietta harbor sites and a minimum at Barge canal sites (Fig. 3A). However, the mean abundance was highest at the barge canal and lowest at the estuary upstream (Fig. 3B).

\section{The spatial patterns of zooplankton communities}

The zooplankton communities at the five sampling sites represented clear spatial patterns of relative species composition and abundance
(Fig. 3C-D). At the five sampling sites, its notable that copepods and rotifers were the main contributors to the taxonomic composition of the zooplankton communities. In terms of relative abundance, in addition to copepods which represent the greatest contributor of zooplankton communities in the study area (mainly Oithona nana, Euterpina acutifrons and Parvocalanus crassirostris); two structural types of zooplankton communities can be recognized: 1) those dominated by rotifers (mainly Brachionus plicatilis and Synchaeta okai) at the barge canal and Nile estuary; 2) those dominated by minor holoplankton (mainly Oikopleura dioica) at the coastal region and Damietta Harbor sites.

The spatial distribution and variations of the abundance of copepod larval stages and 


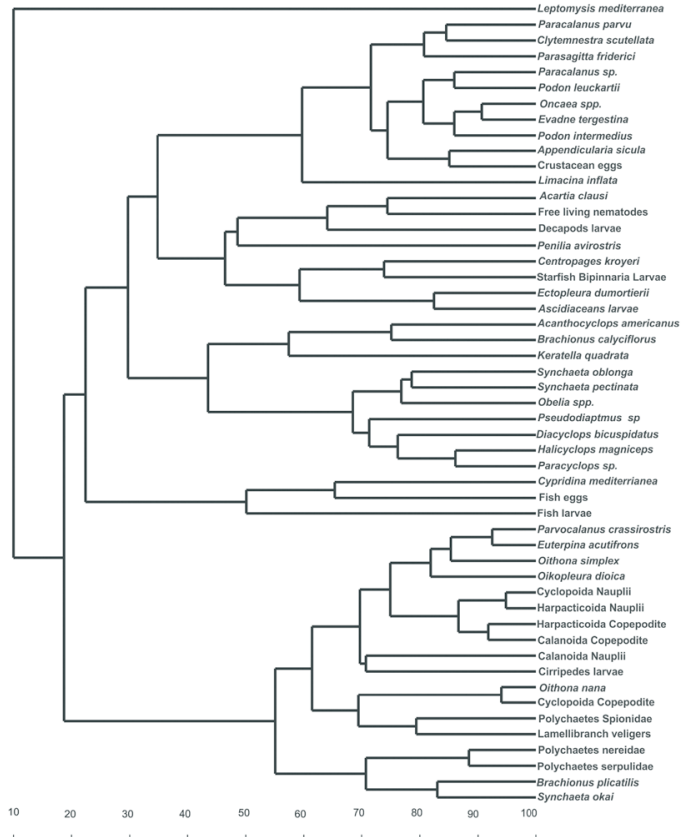

Fig.2. Distribution of zooplankton taxa abundances at the sampling site, plotted using group-average clustering on Bray-Curtis similarities. I-VI= groups I-VI

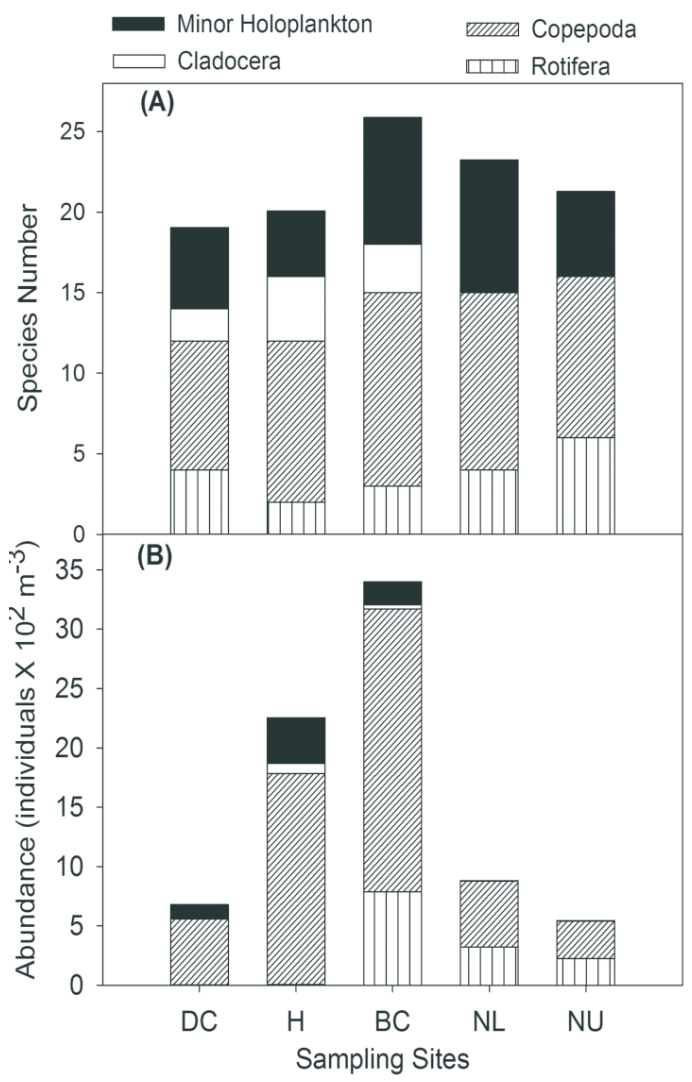

meroplanktonic larvae at each of the five sampling sites were shown in figure 4. Copepodites were the most abundant copepod development stage $(41.6 \%$ of the total), followed by Nauplii (26.7\%). Cyclopoids nauplii and copepodites were the main player of copepod larvae in the study area; harpacticoids larvae showed their maximum values at the coastal region, Damietta harbor and barge canal. For calanoids larvae, nauplii dominated estuary downstream while the copepodites showed maximum mean values at Damietta harbor and barge canal sites (Fig. 4 A-B).

The meroplanktonic larvae showed clear spatial patterns of abundance in the study area (Fig. 4C-D). The spionides polychaetes and lamellibranch veligers were the main players at the five sampling sites. In terms of relative abundance (Fig. 4D), three structural types of meroplankton communities can be recognized: 1) those dominated by lamellibranch veligers

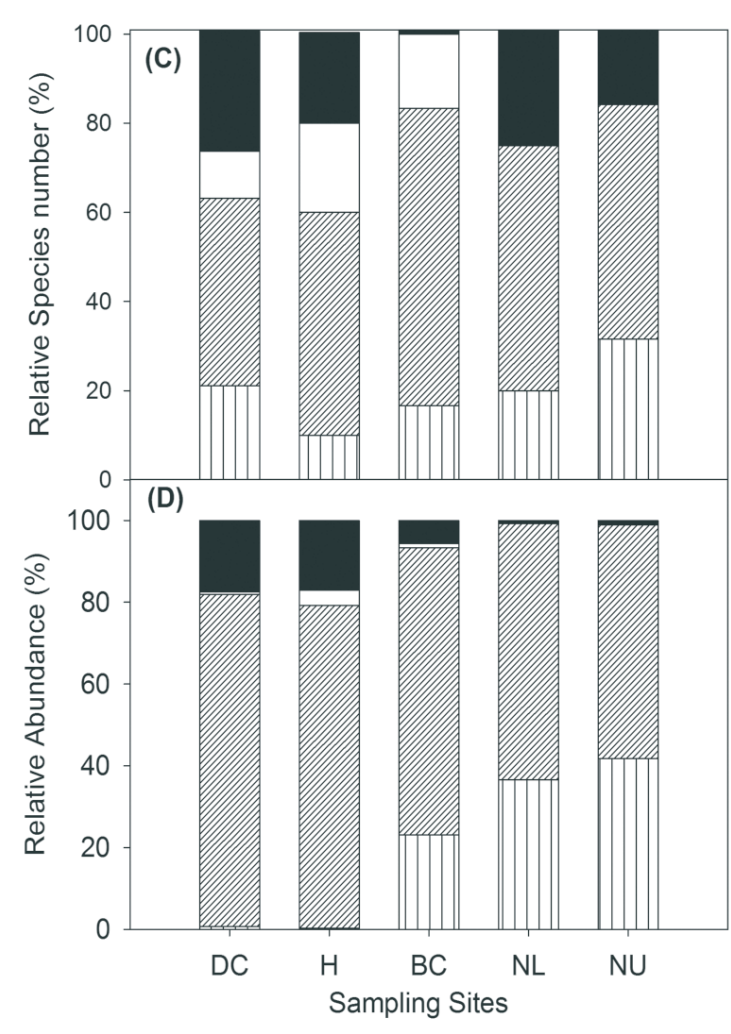

Fig. 3. Spatial variations in species number $(A)$, abundance $(B)$, relative species number $(C)$ and relative abundance $(D)$ of zooplankton in the study area 

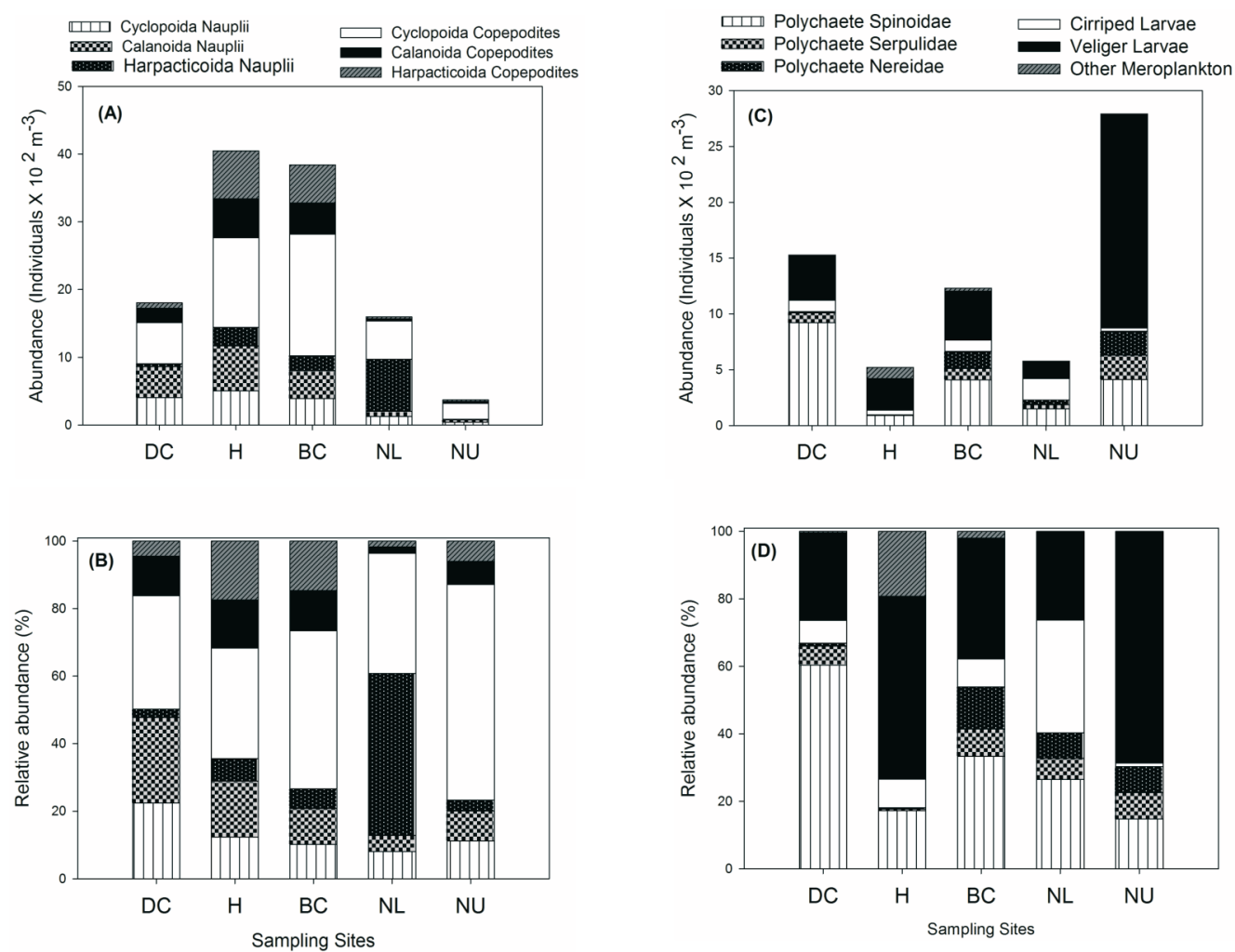

Fig. 4. Spatial variations in copepod larvae abundance (A), relative abundance (B) and meroplanktonic larvae abundance $(C)$, relative abundance $(D)$ in the study area
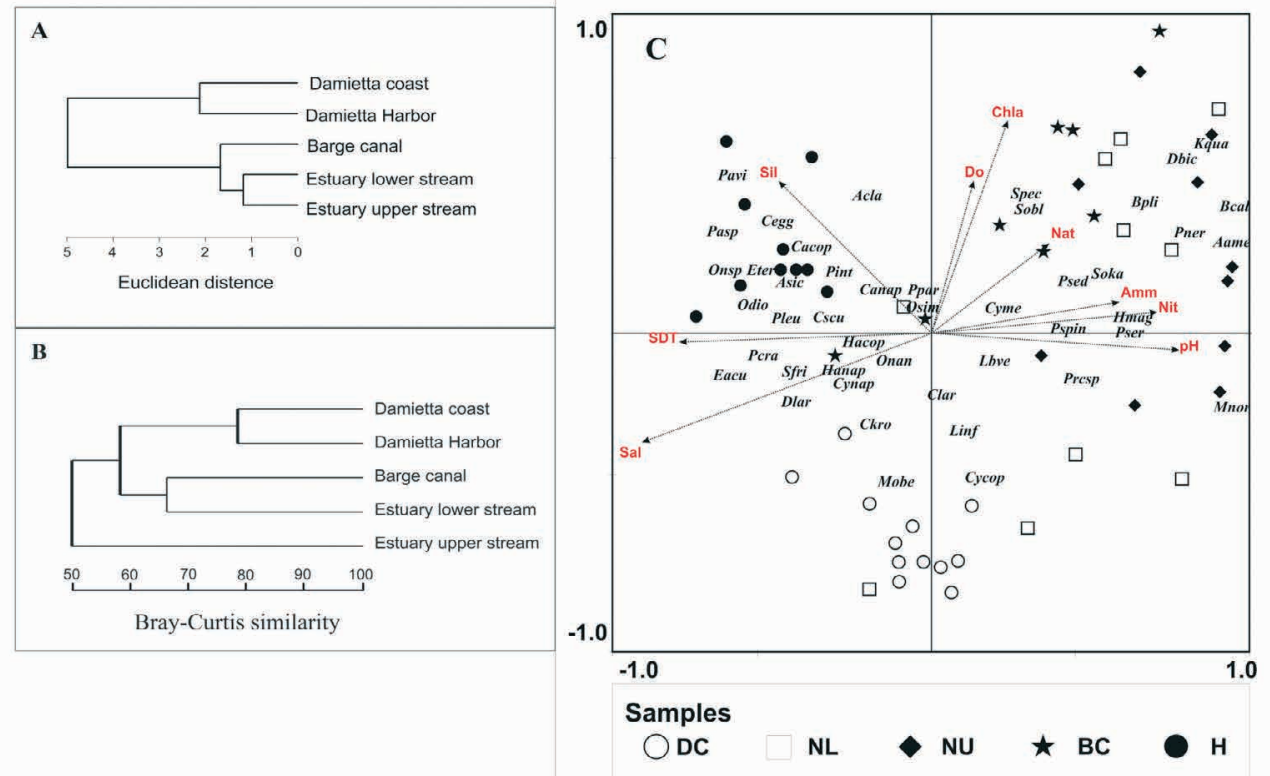

Fig. 5 Cluster analysis of spatial changes of environmental status (A) on Euclidean distance from log transformed environmental data, and for taxonomic patterns of zooplankton communities (B) on Bray-Curtis similarities for speciesabundance data of the five sampling sites, and CCA analysis plot (C) of zooplankton taxa (See Table 2 for abbreviations) as a function of the most significant environmental variables (See Table 1).SDT (Sechi disk Transparency), Sal (salinity), Sil (SiO3), Amm (NH4), Nit (NO2), Nat (NO3), and Chla (chlorophyll a) 
(Damietta Harbor and estuary upstream); those dominated by polychaetes spionidae (the coastal region); those dominated by cirripedes larvae (estuary downstream).

\section{Linkage between zooplankton and environmental variables}

The relationships among the five sampling sites based on data for environmental variables and for zooplankton were summarized by clustering in figure $5 \mathrm{~A}$ and $5 \mathrm{~B}$. This multivariate analysis revealed that the effect of land based effluents clearly appeared by grouping the sampling sites into two clusters: 1) Damietta harbor and the coastal region which were subjected to indirect exposure of land base effluents, 2) Nile estuary and barge canal which were subjected to direct exposure of land base effluents.

The results of the ordination diagram produced by CCA (Fig. 5C) concluded that The vectors of the environmental parameters shown in the diagram explain collectively $71.4 \%$ of the species variance. Salinity which explains alone $29 \%$ of the variance and chlorophyll $a$ had the major significant influences on the distribution pattern of zooplankton species, indicating the effects of land-based effluents throughout the study area. Low salinity taxa (rotifers and majority of freshwater copepods ), lamellibranch veligers, polychaete larvae and cyclopoid copepodites were mainly correlated with the vectors for phytoplankton biomass, nitrogenous nutrients and $\mathrm{pH}$ toward Nile estuary and barge canal indicating a great affinity of these taxa for the terrestrial effluents and the high trophic conditions. Conversely, marine taxa in addition to most of the copepod larvae were generally associated with the vectors of salinity and the secchi disc transparency toward Damietta coastal region and harbor.

\section{DISCUSSION}

The Damietta coastal area and adjacent marine environment are under risk of discharged wastewaters from both drains and ballast water. These pollutants cause dysfunctions in the food web that might lead to total ecosystem imbalance. In our study, both clustering and canonical corresponded analyses revealed clear spatial patterns of both status of environmental and community structures which is clearly due to the effects of land-based effluents. For example, the more affected sites by freshwater discharge (Nile estuary and Barge canal) were separated from the less affected sites (Damietta harbor and coastal region). Also, canonical corresponded analyses revealed that the variations in the zooplankton assemblages between these regions were mainly a function of variations in salinity which had the major effect on zooplankton, in addition to food availability (e.g. phytoplankton biomass). These observations support those considered salinity is the most important environmental variable determining spatial patterns of zooplankton (KINNE, 1971; COLLINS \& WILLIAMS, 1982; FRONEMAN, 2002; KIBIRIGE \& PERISSINOTTO, 2003; MARQUES et al., 2007) and others accounted food availability (PERISSINOTTO et al., 2000; FRONEMAN, 2004; ELTOHAMY, 2012). Our data evidenced also clear spatial salinity gradients associated to marine and brackish water faunal gradients. The differences in abundance of zooplankton groups between the sampling sites are related to distinct hydrological conditions. Freshwater discharges occur mainly in the barge canal and Nile estuary sites resulting in brackish water conditions, added to nutrient enrichment which clearly affecting zooplankton abundances. In the Damietta coast and harbor, salinity changes are slighter due to more stable water column and water masses. For example, copepods, cladocerans, and larvaceans showed higher densities in the low saline water of barge canal, but in Damietta harbor with high salinities. This finding could be attributed to the good water quality and growth conditions in Damietta harbor (ELTOHAMY, 2005). In the barge canal, it seems that the nutritional advantages (high phytoplankton biomass) exceed the denaturation of water quality by the excess land-based effluents. However, the low densities of the previous zooplankton categories at both coastal region, which nearly hydrologically similar to Damietta harbor, and Nile estuary with high phytoplank- 
ton biomass may refute the previous argument. The differences in the response of most of the zooplankton groups to the changes in salinity in each site indicated that the zooplankton distribution in estuaries and coastal systems are not only determined by salinity variations but also other lurking environmental stressors such as pollution (SAUTOUR \& CASTEL, 1995; GORDINA et al., 2001).

In general, the zooplankton community is dominated by the copepod. The cyclopoid Oithona nana was the most abundant taxon at all sampling sites because it has the ability to consume a much wider range of food than other copepods (LAMPITT \& GAMBLE, 1982) and its very important in many neritic regions that are exposed to eutrophication (RICHARD \& JAMET, 2001). According to JEFFERSON (2004), anthropogenic activities such as coastal eutrophication may cause replacement of large copepods with small ones. UYE (1994) compared the copepod communities of 2 eutrophic embayments in Japan, Tokyo Bay, and Osaka Bay. In the more eutrophic Tokyo Bay, the small cyclopoid as Oithona sp. was the dominant, while in the less eutrophic Osaka Bay, the community was dominated by larger copepods. Euterpina acutifrons and Parvocalanus crassirostris were other important copepod species, with wide distribution in the Egyptian Mediterranean coast (NOUR EL-DIN, 1987; ABDEL-AZIZ \& ABOUL-EZZ, 2004; ABDEL-AZIZ et al., 2007; ABOUL-EZZ et al., 2014). Both species are considered to be indicators for estuarine habitat and coastal waters (BJÖRNBERG, 1963; PORTO-NETO, 2003). The presence of the copepod Pseudodiaptomus trihamatus at the Nile estuary and Barge canal, which didn't record in the Mediterranean sea before, may be caused by ship ballast water at the Damietta harbor. In aquatic systems shipping enabled the invasion of species through ballast water into areas similar to their native habitats (CARLTON \& HODDER, 1995). This copepod is native to Indio pacific coast was introduced to Northeastern Brazilian coast through shrimp breed stocks which imported from Taiwan (FERREIRA et al., 2009), where the copepod occurs as a natural component of the zooplankton community (LO et al., 2004). It was recorded only in the Nile river estuary and Barge canal during our study, in narrow salinity intervals (23-31 ppt). We found copepodite stages as well as adult females, indicating the reproductive success of this species. Additional sampling is urgently needed in the relatively less-studied southeastern Mediterranean coast of Egypt (Damietta to Portsaid governorates) to determine whether the species is restricted to the presently reported locations, or is expanding its occurrence.

Nauplii of copepods $(17.5 \%$ of the total zooplankton), copepodites ( $27.2 \%$ ) which could be attributed to high density of older stages of copepods, also Bivalve larvae, cirriped and polychaete larvae demonstrated to be important components of the plankton in the study area, as in typical of many estuaries and coastal waters (NEALE \& BAYLY, 1974; GAUGHAN \& POTTER, 1995; MARTIN et al., 1997; GONCALVES et al., 2010). Nauplii and copepodites were clearly abundant at all sampling sites except at the estuary upstream and this may be due to the bad water quality or competition with other filter feeders such as molluscs veligers. The low abundance of nauplii comparing to the copepodites could be attributed to predation by large invertebrates such as chaetognaths, and medusa and also omnivorous copepods, including Oithona (UCHIMA \& HIRANO, 1986) all of which were present in our study region. Cyclopoid nauplii and copepodites were clearly abundant at all sampling sites except at the estuary downstream where the community was dominated by calanoid nauplii. SOTO \& HURLBERT (1991) showed that calanoids could be strongly depressed cyclopoid populations by either a reduction of phytoplankton for cyclopoid nauplii or by calanoid predation on cyclopoid nauplii.

The highest rotifers densities were associated with eutrophied sites of excess land-based effluents (Barge canal and Nile estuary). This increasing may be proportional to food availability (phytoplankton biomass), and as a possible increase in bacteria as food increase numbers of bacteriophagus rotifers (PEJLER, 1983; NEUMANNLEITÃO et al., 1992). Several authors (HOBBIE \& COLE, 1984; CONLEY et al., 2009) noticed a kind 
of relationship between the increase in bacteria number with increasing eutrophication. The low rotifers densities at the other sites (Damietta coast and harbor) suggests that conditions, either predation (TELESH, 1993) or physiological constraints of salinity (MEDEIROS et al., 2010), were not suitable to sustain populations

According to SAUTOUR \& CASTEL (1995), the meroplanktonic populations may be related to differences in benthic habitat rather than changes in environmental variables. Cirriped larvae are more abundant and represented in the estuary downstream, possibly because the presence of hard substratum that can provide the settlement areas for cirriped populations. The polychaete larvae were dominated by the spinoids. Spinoids are common predominant members of meroplankton (MARTIN et al., 1997), and this may be attributed to the extent of mudflats through the study area which may provide an excellent habitat for spinoids; observation similar to that of (LEVIN, 1984). The dispersive distribution of bivalve larvae throughout the study area, however, due to the wide variety of biophysical factors rather than structures of benthic habitat. Larval survival and development are dependent upon turbidity ranges and markedly affected by fluctuations in food abundance, food quality and predator abundance (PULFRICH, 1997). This to some extent explains our results where the significant increase in density of bivalve larvae in the estuary upstream may be related to food availability and/or reduced predation by marine animals due to physiological constraints of salinity.

\section{CONCLUSIONS}

In general, zooplankton and the main taxonomic categories showed reasonable differences among the sampling sites, and they were significantly related to the spatial changes of environmental variables. The comparative results of zooplankton abundance and distribution in the study area indicate that the Damietta harbor and barge canal have good growth conditions, whilst the Nile estuary, particularly its upstream has poor conditions that limit normal zooplankton activity which undoubtedly due to land base effluents.

\section{ACKNOWLEDGEMENTS}

The authors wish to express sincere appreciation to Prof. T. Chad WALTER, Smithsonian Institution, Department of Invertebrate Zoology, Museum Support Center, Suitland, for his identification for the calanoid copepod Pseudodiaptmus trihamatus. A special thanks to prof. R. RUSSELL. Hopcroft and prof. E. M. Nagwa ABDEL AZIZ for constructive comments.

\section{REFERENCES}

ABDEL-AZIZ, N. E. \& S. M. ABOUL-EZZ. 2004. The structure of zooplankton community in Lake Maryout, Alexandria, Egypt. Egypt. J. of Aquat. Res., 30(A): 160-170.

ABDEL-AZIZ, N. E., A. E. GHOBASHI, M. M. DORGHAM \& W. S. ELTOHAMY. 2007. Qualitative and quantitative study of copepods in damietta harbor, egypt. Egypt. J. of Aquat. Res., 33(1): 144-162.

ABOUL-EZZ, S. M., N. E. ABDEL-AZIZ, M. M. ABOU ZAID, M. EL RAEY \& H. A. ABO-TALEB. 2014. Environmental assessment of El-Mex Bay, Southeastern Mediterranean by using Rotif- era as a plankton bio-indicator. Egypt. J. of Aquat. Res., 40(1): 43-57.

AZRINA, M. Z., C. K. YAP, A. R. ISMAIL, A. ISMAIL \& S. G. TAN. 2006. Anthropogenic impacts on the distribution and biodiversity of benthic macroinvertebrates and water quality of the Langat River, Peninsular Malaysia. Ecotox. Environ. Safe., 64(3): 337-347.

BJÖRNBERG, T. K. S. 1963. On the marine free-living copepods off Brazil. Bolm. inst. oceanogr., 13(1): 3-142.

BOLTOVSKOY, D. 1999. South Atlantic Zooplankton. Backhuys Publisher. The Netherlands 
(Leiden), 1706 pp.

BONNET, D. \& C. FRID. 2004. Seven copepod species considered as indicators of water-mass influence and changes: results from a Northumberland coastal station. ICES J. Mar. Sci., 61(4): 485-491.

BRAY, J. R. \& J. T. CURTIS. 1957. An ordination of the upland forest communities of southern Wisconsin. Ecol. Monogr., 27(4): 325-349.

CARLTON, J. T. \& J. HODDER. 1995. Biogeography and dispersal of coastal marine organisms: experimental studies on a replica of a 16thcentury sailing vessel. Mar. Biol., 121(4): 721-730.

COLLINS, N. R. \& R. WILLIAMS. 1982. Zooplankton Communities in the Bristol Channel and Severn Estuary. Mar. Ecol-Prog. Ser., 9(1): $1-11$.

CONLEY, D. J., H. W. PAERL \& R. W. HOWARTH. 2009. Controlling eutrophication: nitrogen and phosphorus. Science, 323(5917): 10141015.

DODSON, S. I., R. A. LILLIE \& S.WILL-WOLF. 2005. Land use, water chemistry, aquatic vegetation, and zooplankton community structure of shallow lakes. Ecol. Appl., 15(4): 11911198.

DORIS, S. \& H. H. STUART. 1991. Long-term experiments on calanoid-cyclopoid interactions. Ecol. Monogr., 61(3): 245-265.

EDMONDSON, W. T. 1959. Freshwater biology. 2nd Edition. John Wiley \& sons puplisher. New York, London, Sydney, 1248 pp.

EL-GHOBASHY, A. E. 2009. Natural fish fry food of seven commercial species in the Egyptian Mediterranean water. World Appl. Sci. J., 7(3): 320-331

ELTOHAMY, W. S. 2005. Zooplankton community in Damietta Harbor. Thesis, University of Mansoura, 219 pp.

ELTOHAMY, W. S. 2012. Food relations between larvae of economic fishes and zooplankton in some Egyptian coastal areas of the Mediterranean Sea.Thesis, University of Mansoura, $228 \mathrm{pp}$.

FALCÃO, J., S. C. MARQUES, M. A. PARDAL, J. C. MARQUES, A. L. PRIMO \& U. M. AZEITEIRO. 2012. Mesozooplankton structural responses in a shallow temperate estuary following restoration measures. Estuar. Coast. Shelf S., 112: 23-30.

FERREIRA, C. E. L., A. O. R. JUNQUEIRA, M. C. VILLAC \& R. M. LOPES. 2009. Marine bioinvasions in the Brazilian coast. In: G. RILOV \& J A. CROOKS (Editors). Brief report on history of events, vectors, ecology, impacts and management of non-indigenous species. Biological Invasions in Marine Ecosystems. Springer, Berlin, pp. 459-477.

FLEEGER, J. W., K. R. CARMAN \& R. M. NISBET. 2003. Indirect effects of contaminants in aquatic ecosystems. Sci. Total. Environ., 317(1-3): 207-233.

FRONEMAN, P. W. 2002. Seasonal changes in selected physico-chemical and biological variables in the temporarily open/closed Kasouga estuary, Eastern Cape, South Africa. Afr. J. Aquat. Sci., 27(2): 117-123.

FRONEMAN P. W. 2004. Zooplankton community structure and biomass in a southern African temporarily open/closed estuary. Estuarine, Coastal and Shelf Science, 60(1): 125-132.

GaUghan, D. J. \& I. C. POTTER. 1995. Composition, distribution and seasonal abundance of zooplankton in a shallow, seasonally closed estuary in temperate Australia. Estuar. Coast. Shelf S., 41(2): 117-135.

GONCALVES, A. M. M., M. A. PARDAL, S. C. MARQUES, M. DE TROCH \& U. M. AZEITEIRO. 2010. Distribution and composition of smallsize zooplankton fraction in a temperate shallow estuary (western Portugal). Fresen. Environ. Bull., 19(12b): 3160-3176.

GONZALEZ, J. G. \& T. E. BOWMAN. 1965. Planktonic copepods from Bahia Fosforescente, Puerto Rico and adjacent waters. Proceedings of the United States National Museum. Smithsonian Institution, pp. 241-304.

GORDINA, A. D., E. V. PAVLOVA, E. I. OVSYANY, J.G. WILSON, R. B. KEMP \& A. S. ROMANOV. 2001. Long-term changes in Sevastopol Bay (the Black Sea) with particular reference to the ichthyoplankton and zooplankton. Estuar. Coast. Shelf S., 52(1): 1-13.

HAMMER, O. D., A. T. HARPER \& P. D. RYAN 2001. Paleontological Statistics software package 
for education and data analysis. Paleont. Electron, 4(1): 1-9.

HAMZA, W. 2006. The Nile Estuary. Estuaries. Springer, Heidelberg, pp. 149-173.

HOBBIE, J. E. \& J. J. COLE. 1984. Response of a detrital foodweb to eutrophication. B Mar. Sci., 35(3): 357-363.

IBRAHIM, W. A. 2011. An overview of bird migration studies in Egypt. The Ring, 33(1-2): $55-75$

JEFFERSON, T. T. 2004. The importance of small planktonic copepods and their roles in pelagic marine food webs. Zool. Stud., 43(2): 255-266.

KIBIRIGE, I. \& R.PERISSINOTTO. 2003. The zooplankton community of the Mpenjati Estuary, a South African temporarily open/closed system. Estuar. Coast. Shelf S., 58(4): 727741

KINNE, O. 1971. Salinity: invertebrates. Marine Ecology. In: O. KINNE (Editor). Wiley-Interscience, New York, pp. 821-996.

KOLAR, C. S \& D. M. LODGE. 2001. Progress in invasion biology: predicting invaders. Trends. Ecol. Evol., 16(4): 199-204.

LAMPITT, R. S. \& J. C. GAMBLE. 1982. Diet and respiration of the small planktonic marine copepod Oithona nana. Mar. Biol., 66(2): 185-190.

LEONARDO, K. M., M. J. MAURO \& M. L. RUBENS. 2009. Estuarine and oceanic influences on copepod abundance and production of a subtropical coastal area. J. Plankton Res., 31(8): 815-826.

LEVIN, L. A. 1984. Life history and dispersal patterns in a dense infaunal polychaete assemblage: community structure and response to disturbance. Ecology, 65(5): 1185-1200.

LEVINTON, J. S. 2001. Marine biology: function, biodiversity, ecology. Oxford University Press New York. New York, 420 pp.

LO, W. T., C. L. CHUNG \& C. T. SHIH. 2004. Seasonal distribution of copepods in Tapong Bay, southwestern Taiwan. Zool. Stud., 43(2): 464-474.

MARQUES, S. C., M. A. PARDAL, M. J. PEREIRA, F. GONÇALVES, J.C. MARQUES \& U.M. AZEITEIRO. 2007. Zooplankton distribution and dynamics in a temperate shallow estuary. Hydrobiologia, 587(1): 213-223.

MARTIN, D., M. CLARET, S. PINEDO \& R. SARDÁ. 1997. Vertical and spatial distribution of the near-shore littoral meroplankton off the Bay of Blanes (NW Mediterranean Sea). J. Plankton Res., 19(12): 2079-2089.

MCGEOCH, M. A., S. H. M. BUTCHART, D.SPEAR, E. MARAIS, E. J. KLEYNHANS, A. SYMES, J. CHANSON \& M.HOFFMANN. 2010. Global indicators of biological invasion: species numbers, biodiversity impact and policy responses. Divers. Distrib., 16(1): 95-108.

MEDEIROS, A. M. A., J. E. L. BARBOSA, P. R. MEDEIROS, R. M. ROCHA \& L. F. SILVA. 2010. Salinity and freshwater discharge determine rotifer distribution at the Mossoró River Estuary (Semiarid Region of Brazil). Braz. J. Biol., 70(3): 551-557.

MOLINERO, J. C., F. IBANEZ, P. NIVAL, E. BUECHER $\&$ S. SOUISSI. 2005. North Atlantic climate and northwestern Mediterranean plankton variability. Limnol. Oceanogr., 50(4): 1213-1220.

NEALE, I. M. \& I. A. E. BAYLY. 1974. Studies on the ecology of the zooplankton of four estuaries in Victoria. Mar. Freshwater Res., 25(3): 337-350.

NEUMANN-LEITÃO, S., M. N. PARANAGUÁ \& J. L. VALENTIN. 1992. The planktonic rotifers of the estuarine lagunar complex of Suape (Pernambuco, Brazil). Hydrobiologia, 232(2): 133-143.

NISHIDA, S. 1985. Taxonomy and distribution of the family Oithonidae (Copepoda, Cyclopoida) in the Pacific and Indian Oceans. Bulletin of the Ocean Research Institute, University of Tokyo. Tokyo, $167 \mathrm{pp}$.

NOUR EL-DIN, N. M. N. 1987. Ecology and distribution of pelagic copepods in the Mediterranean waters of Egypt. Thesis, University of Alexandria, $213 \mathrm{pp}$.

OMAR, W. M. W. 2010. Perspectives on the use of algae as biological indicators for monitoring and protecting aquatic environments, with special reference to Malaysian freshwater ecosystems. Trop. L. Sci. Res., 21(2): 51.

PEJLER, B. 1983. Zooplanktic indicators of trophy and their food. Hydrobiologia, 101(1): 111- 
114.

PERISSINOTTO, R, D. R. WALKER, P. WEBB, T. H. WOOLDRIDGE \& R. BALLY. 2000. Relationships between zoo-and phytoplankton in a warm-temperate, semi-permanently closed estuary, South Africa. Estuar. Coast. Shelf S., 51(1): 1-11.

PORTO-NETO, F. F. 2003. Zooplankton as Bioindicator of Environmental Quality in the Tamandaré Reef System, Pernambuco, Brazil: Anthropogenic Influences and Interaction with Mangroves. Thesis, University of Bremen, 131 pp.

PULFRICH, A. 1997. Seasonal variation in the occurrence of planktic bivalve larvae in the Schleswig-Holstein Wadden Sea. Helgoland. Mar. Res., 51(1): 23-39.

RICHARD, S. \& J. JAMET. 2001. An unusual distribution of Oithona nana Giesbrecht (1892) (Crustacea: Cyclopoida) in a bay: the case of Toulon Bay (France, Mediterranean Sea). J. Coastal Res., 7 (174): 957-963.

SAUTOUR, B. \& J. CASTEL. 1995. Comparative spring distribution of zooplankton in three macrotidal European estuaries. Hydrobiologia, 311(1-3): 139-151.

SOTO, D. \& S. H. HURLBERT. 1991. Long-Term Experiments on Calanoid Cyclopoid Interactions. Ecol. Monogr., 61(3): 245-265.
STRICKLAND, J. D. H. \& T. R. PARSONS. 1972. A Practical Handbook of Seawater Analysis. 2nd Edition. Fisheries Research Board of Canada. Ottawa, 310 pp.

TELESH, I. V. 1993. The effect of fish on planktonic rotifers. Hydrobiologia, 255/256: 289-296

TREGOUBOFF, G. \& M. ROSE. 1957. Manuel de Planctologie Mediterranee. I (texte). CNRS. Paris, $587 \mathrm{pp}$.

UCHIMA, M. \& R. HIRANO. 1986. Food of Oithona davisae (Copepoda: Cyclopoida) and the effect of food concentration at first feeding on the larval growth. Plankton Benthos Res., 33: 21-28.

UYE, S. 1994. Replacement of large copepods by small ones with eutrophication of embayments: cause and consequence. Hydrobiologia, 292(1): 513-519.

VADADI-FÜLÖP, C., L. HUFNAGEL, G. JABLONSZKY \& K. ZSUGA. 2009. Crustacean plankton abundance in the Danube River and in its side arms in Hungary. Biologia, 64(6): 1184-1195.

VARELA, M., A. BODE, J. LORENZO, M.T. ALVAREZ-OSSORIO, A. MIRANDA, T. PATROCINIO, R. ANADON, L. VIESCA, N. RODRÍGUEZ \& L. VALDÉS. 2006. The effect of the "Prestige" oil spill on the plankton of the N-NW Spanish coast. Mar. Pollut. Bull., 53(5-7): 272-286.

Received: 18 January 2017

Accepted: 29 April 2017 


\title{
Zooplankton stresnih područja uzduž obale Damietta (Egipat) u Sredozemnom moru
}

\author{
Wael S. ELTOHAMY*, Ahmad ALZENY i Yasmine A. M. AZAB \\ *Kontakt e-adresa: waelsalah@du.edu.eg
}

\begin{abstract}
SAŽETAK
Istraživana je prostorna struktura zooplanktonskih zajednica na obali Damietta (Egipat, jugoistočni Mediteran) kako bi se procijenio utjecaj ljudskih aktivnosti na obilje i strukturu zajednice. U lipnju i srpnju 2014. uzorkovano je na dvadeset pet postaja s pet različitih mjesta izloženih zagađenju. Uz larve veslonožaca i meroplanktona zabilježene su 34 zooplanktonske vrste. Veslonošci se bili najbrojnija skupina među kojima su najčešći Oithona nana, Euterpina acutifrons i Parvocalanus cirrostratus.

Kalanoidni veslonožac Pseudodiaptomus trihamatus je novi nalaz za Sredozemno more, a vjerojatno je da je možda unesen putem balastnih voda. Multivarijatne / jednosmjerne analize pokazale su da 1) varijable okoliša i zooplanktonske zajednice predstavljaju značajne razlike između pet mjesta; 2) prostorne varijacije strukture zajednice nedvojbeno su posljedica tehnoloških otpadnih voda (pročišćenih i nepročišćenih) sa kopna; i 3 ) između svih varijablia okoliša, saliniteta i biomase fitoplanktona imali su glavne utjecaje na prostorne obrasce kategorija zooplanktona. Rezultati pokazuju da je samo ne ispuštena voda rizična za obalu Damiette, već i balastna voda, koja nije nimalo manje opasna. Stoga se naglašava potreba za aktivacijom upravljanja balastnim vodama kako bi se smanjio rizik unosa invazivnih vrsta.
\end{abstract}

Ključne riječi: zooplankton, ispusne kopnene vode, obala Damietta, veslonošci, Pseudodiaptomus trihamatus 
